\title{
The optimization of development process of petrol-gas stations network with the purpose to increase energy efficiency
}

\begin{abstract}
Development of petrol/gas stations network requires a complex approach to the assessment of environmental impact. The use of appropriate indicators according DPSIR methodology enables optimization of processes at oil/gas stations and increase energy efficiency.

Use of renewable energy and new insulating materials has great importance to reduce energy consumption for heating of petrol/gas stations buildings. As a replacement styropor and styrodur (for added insulation of walls and floors) is much more efficient to use blocks of innovative insulating materials in the construction of new facilities.

Widespread application of renewable energy and thermal insulation materials in buildings of oil/gas stations, reducing electricity consumption by using energy-saving LED technology, as well as savings in transportation fuels reducing the weight of tankers using Al alloys and composite materials are the basic methods of increasing energy efficiency. The use of Al alloys in tankers and reservoirs design conductive to increase corrosion resistance.
\end{abstract}

Keywords: petrol/gas station, optimization, DPSIR methodology, indicators, energy efficiency, sustainable energy sources, LED technology, corrosion resistance, Al alloys.

\section{INTRODUCTION}

The strategy of building and development of any retail trade chain is a multivariate permanent management process. Retail network of multi-service stations imposes on this process a significant number of additional conditions and functions, the most important of which are the factors of influence on the environment. The number of laws and regulations governing the procedures and control mechanisms is colossal, and the number of technical parameters describing the environmental impact and governing of technical processes is enormous.

A network of petrol and gas stations in addition to providing consumers with oil products, which themselves are a threat to the environment, is obliged to protect staff, customers, neighboring households and industrial facilities, and to ensure a minimum level of impact on the environment (water, air and soil).

The development strategy cannot be limited to the description of technical methods, because such formulaic solutions describe the common cases, and they are not tailored to the specific location of the object and the features of its environment. Business effects of the strategy can be offset by problems caused during the exploitation of petrol/ gas stations network, while the errors in the design

Author's address: ${ }^{1}$ ALFA University, Belgrade, Serbia, ${ }^{2}$ Lukoil, Moscow, Russia, ${ }^{3}$ UNION - Nikola Tesla University, Belgrade, Serbia

Received for Publication: 15. 09. 2014.

Accepted for Publication: 20. 11. 2014. of standard solutions can be multiplied on the entire network and the region.

The aim of this work is to analyze the possibility for application of DPSIR methodology in the design and exploitation of petrol/gas stations network on purpose to increase energy efficiency and corrosion protection of tankers.

\section{OBJECTS AND METHODS}

Because of the complexity of the issue, strategy development and a planning network of retail trade in petrol/gas stations, it is necessary and advisable to use a systematic approach. One of the most successful mechanisms of systematic approach is the system of the environmental indicators, based on the methodology developed by the European Environmental Agency (EEA), and the analysis of the interaction of environmental and technological impacts using indicators based on the model DPSIR [4]. The EEA assesses the state (S) of the environment using DPSIR methodology. The state $(S)$ is the result of

- specific drivers (D),

- $\operatorname{pressures}(\mathrm{P})$, positive or negative,

- impact (I) on the environment.

The responses $(\mathrm{R})$ represent the solutions (policies, investments) that should then be done to improve or maintain that state.

The report also looks at outlooks $(\mathrm{O})$ for the state of the environment - namely, what will happen with that state over time (e.g. 2020, 2050) based on various scenarios [EEA, DPSIR, 2010]. 


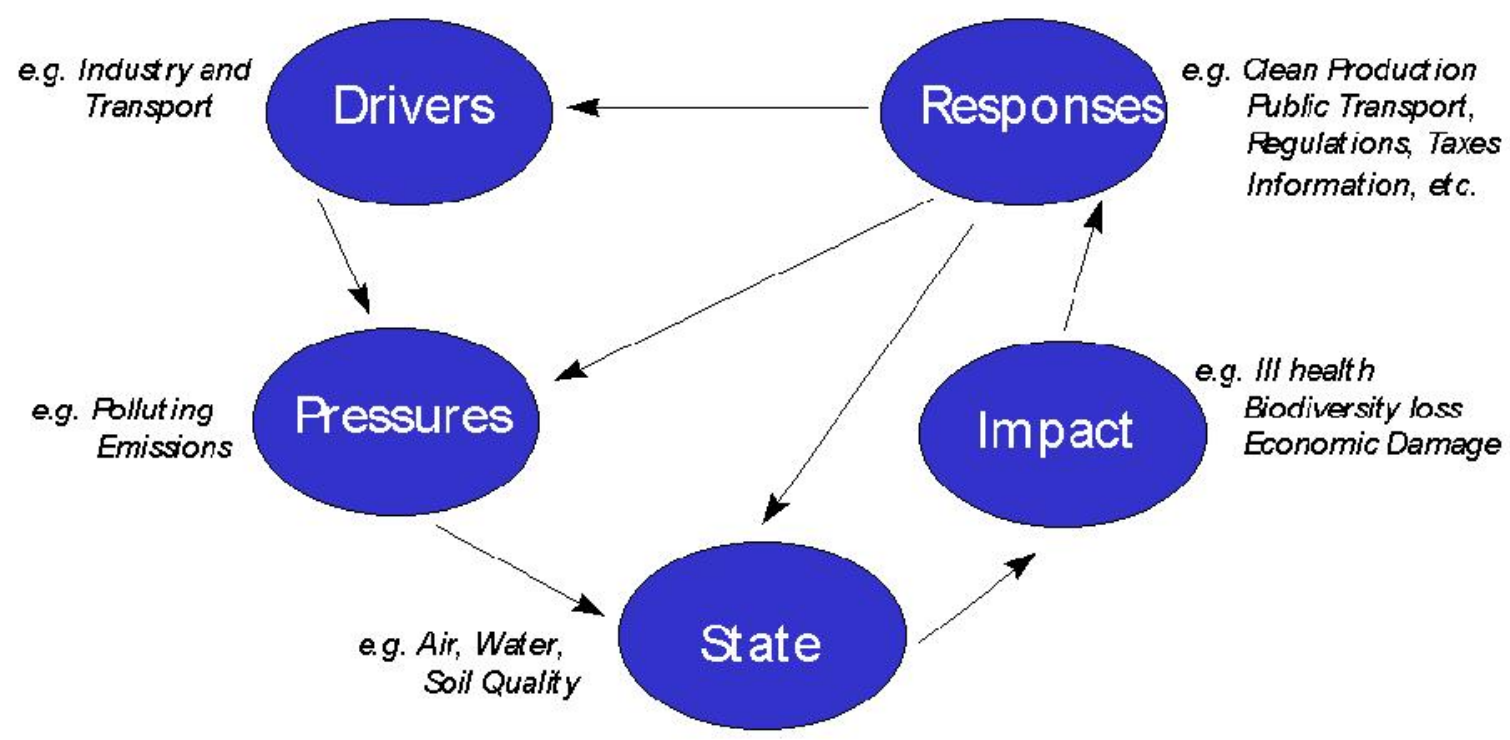

Figure 1 - DPSIR framework [4]

Use of the model simplifies and formalizes the description of the problems, creating a pattern of administrative, organizational and technological factors (events) in the design of the system, and in response to the corresponding indicator, including preventive measures and emergency response in the event of emergency.

Below we discuss some specific examples of possible applications and uses of a system of indicators in different situations, and how to improve such indicators in the design, post-project and exploitation of petrol/gas stations.

\section{CONSTRUCTION OF THE TANKS AND THE SUPPLYING INFRASTRUCTURE OF THE PETROL/GAS STATION}

When designing the disposition of tanks with oil and liquefied natural gas, as well as the infrastructure of pipes and valves, providing the circulation of products, it is necessary to take into consideration the following features of operation that have a complex effect on the environment [9].

Systems of airway valves of oil tanks continually lead to evaporation of light fractions of petroleum products, which affect the air, earth, soil, water, etc. If the constructive solution combines two kinds of oil (gasoline and diesel) in the same apparatus, the amount of emitted fumes increases. When draining of oil products from the cistern, the total volume of the air mixture containing a significant amount of light fractions in the amount of 10 to $40 \mathrm{~m}^{3}$ falls into the atmosphere. The problem can be solved using a number of additional technical elements of reinforcement and implementation of separate valves.
Gas tanks do not use breathing valves, but the system of the safety valves in the tank is triggered when the nominal pressure in the tank exceed of $25 \mathrm{~atm}$ and 12-20 atm in the installation system. The system releases a small amount of gas always when refueling a vehicle or a container. The scheduled amount of the gas ejection is affected by the increase of temperature in the reservoir more than 28-30 degrees centigrade, the amount and frequency of the circulation in the system, container filling procedure, and other processes. The problem can be solved by the correct setting and monitoring of a booster pump.

The groundwater can be a significant problem in the exploitation of gas stations. In the case of improperly designed base and mountings of the tank, as well as untimely preventive measures, the reservoir may float, damaging elements, installations and fittings, which will inevitably lead to the risk of oil spills with the most negative impact on the environment (soil, water, air) and the population.

Leaking fuel and the warning systems and prevention: horizontal and vertical metal tanks have relatively short lifetime, usually 20 years. Depending on soil acidity a lifetime can be signifycantly reduced. In view of the fact that in Serbia is only allowed exploitation of underground storage tanks, the unique indicator of the correctness of its use is the system alerts of leaks and the oil level control.

On the site, during overload of petroleum products, as a rule, there is an uncontrollable shedding of fuel as a result of misuse of the equipment dispenser. During exploitation of these installations 
(pipelines), in the case of deviations and violations in the installation of such equipment, after some time (months or years) occurs leakage of oil to the ground. To resolve this issue, a system for the collection and treatment of wastewater from the site with a separator is provided, with the return of the primary treated water into the sewage system. System for collection and treatment of waste water from the site must be periodically cleaned by specialized enterprises, with removing sediments outside gas stations by licensed carriers. Controlling body has the right to verify the quality and quantity of work done, including by requesting primary dispatch notes.

Fire protection systems and activities are provided in the form of two main procedures: preventive and periodic control measures and actions of plant personnel and specialized units in the event of an accident. Between all the cases of the impacts on the environment - fire on gas station is the most disastrous in its consequences because of the lack of opportunities to eliminate them.

Restoration and reclamation: soil remediation is necessary not only in the case of an accidental release of oil, but also after the long-term use of gas stations, because there is currently no technology that completely eliminates the ingress of oil into the soil.

\section{FEATURES OF STORAGE, SALE OF PACKAGED MOTOR OILS AND OIL CHANGE POINTS}

In Serbia, the implementation of engine oil in leaky packaging is currently banned. This requirement is associated with a significant negative impact on the environment. There are also regulations prescribing enterprises implementing such products, the obligation to ensure the reception of waste oil and transport it to a specialized processsing firm. At present, a company is accountable for the amount of imported packaging material by paying the appropriate taxes. In the case when the regulatory acts will come into full force for the gas stations becomes actual formation of oil change points and oil collection points.

Oil change points allow quickly and accurately extract waste oil from the engine, and replace it with a new one. The amount of lost product in this case, and hence the impact on the environment, is greatly reduced.

At many gas stations there exist integrated, automated and semi-automated carwashes. Legislation provides the phased introduction of fees for the amount of water discharged into the sewer system, thus installing treatment systems and water recycling becomes a pressing issue.
Oil change points equipped with systems for water collection and its primary treatment using separators highly reduce the risk of uncontrolled leaks and accidents.

\section{OPTIMIZATION OF OPERATING PROCEDURES FOR PETROL/GAS STATIONS AND THE USE OF RESOURCE-SAVING TECHNOLOGIES AND RENEWABLE ENERGY SOURCES}

Installation of electric heating systems based on oil convection radiators allows ensuring the normal circulation of heat, reducing the overhead for heating, with minimal impact on the composition of the air in the room. Using the heat-curtain in front entrance combined with automatic sliding doors provides the optimal composition of fresh air in the room with minimal heat loss.

For complex oil/gas stations, in terms of economy and environmental impact, the source of used water often is critical point. Purified fresh drinking water from the system of urban or regional water supply is expensive, hence the wells may be used to obtain technical water, which together with a system of primary treatment, recycling and retreatment follow-up, combined with a system of separators provides cost-effectiveness and reduces environmental impact. The delivery of service water at the gas station is obligatory.

The combination of the cooling systems of a built-in refrigerators and open cabinets for drinks and food with the main air-conditioning system optimizes the load in summer. Indeed, an additionnal cooling takes place through the commercial equipment while refrigerator radiates heat over the rear wall into the same space, hence such combination significantly reduces the use of electricity for each unit separately.

Saving technologies allow combining several business decisions. For example, if the gas station is located near a source of geothermal energy, this resource can be used to generate electricity. Since the station has already qualified service personnel, and system security, and the government provides preferential rates for the production of energy from renewable sources, this project could be beneficial, provided to solve some technical problems [5].

Installation of solar-powered heating systems with accumulation of hot water in the heat insulating tanks allows for customers and staff of oil/gas station required amount of hot water around the clock and, when using a small recirculation systems, to produce additional heating for support facilities during the winter in Serbia $[7,8]$.

Light-emitting diode (LED) is a semiconductor light source. LEDs are used for lighting of petrol/gas stations and ancillary buildings. By installing LEDs for indoor and outdoor lighting and 
motion sensors in offices and support facilities the energy consumption can be reduced up to $20 \%$ without loss of brightness level of the illuminated area. Compared with other electric light sources LEDs have the following advantages: high efficiency and long life $(30,000$ to 100,000 hours). These characteristics make LEDs suitable for tankers illumination [6].

An increase of energy efficiency on installations of reactive power compensators can not only reduce the total cost of electricity, but also greatly improve the quality characteristics of the local energy supply, with all its consequences [1]. There are actual savings of up to $10 \%$ depending on the power consumption and the composition of the electrical equipment.

\section{PROTECTION OF RESERVOIRS AND TANKS FROM CORROSION}

The main methods of anticorrosion protection include metal alloying, heat treating, inhibiting the environment surrounding the metal and protective coatings. In the case of electrochemical corrosion by doping, the metal proceeds from the active to the inactive state, thereby forming a passive film with high barrier properties. For example, alloying iron with chromium allowed to transferring iron into stable passive state and creating a whole class of alloys, called stainless steels [9]. Additional alloying of stainless steels with molybdenum and nickel eliminates the tendency to pitting [10]. Stainless steel is corrosion-resistant due to alloying $\mathrm{Cr}, \mathrm{Ni}$, $\mathrm{Nb}$ and Ti components (12-18\%).

To fight corrosion, the metal corrosion inhibitors are widely used. They in small quantities are entered in aggressive environment and create adsorption film on the metal surface, retarding electrode processes and change the electrochemical parameters of metals. Close to this method of protection is thermal diffusion surface alloying steels with chromium, aluminum, silicon or zinc to improve heat - and corrosion resistance in aggressive environments. Intensively developed are two types of steel. Some of them are low alloys intended to be used at ambient temperature, which must be resistant to corrosion in the presence of $\mathrm{H}_{2} \mathrm{~S}[2,3]$.

The objective of aluminum alloys development is the use of materials with low specific weight and increased corrosion resistance for the tankers construction. Therefore aluminum alloy with lithium is intensively developed, in which it would be possible to achieve the same strength with about $10 \%$ less specific weight. Taking into account that most of the construction of tankers uses aluminum alloy, the reduction in weight is significant. The second object is achieved by a combination of the aluminum matrix metal carbide, oxide fibers or the alloying of aluminum oxides in a variety of powder. Alloys of aluminum can replace some of the titanium alloys in the manufacturing of tanks and reservoirs with a significant reduction in weight.

The Al-Mg alloys have significant corrosion resistance and hardness. The most commonly used Al-Mg alloys contain 1-5\% Mg. The Al-Mn alloys are used to significantly increase the corrosion resistance [11].

Metalized coatings are very convenient for large products and structures. The refractory metal can be applied by plasma spraying and vapor deposition. Vacuum metallization of products by condensation of metal vapor is used to protect metal surfaces. This method can deposit layers of different thickness of aluminum, nickel, chromium, cadmium, and other metals.

To prevent corrosion of underground and hydraulic structures, as well as the chemical equipment operating with aggressive conductive medium, electrochemical methods of protection are used. Underground structures, such as gasoline storage tanks and pipelines, have corrosion protection of bitumen and asphalt, as well as polymeric tapes and enamels. Protection from stray currents is provided by drainage.

\section{CONCLUSION}

Strategic management of development of retail trade network is a complex model, covering different areas. One of the important parameters of this model is the foresight and planning the level of exposure and the effects on the environment, aggravated by a considerable number of normative and regulatory acts, as well as technological parameters. However, for the purpose of making plans and strategic management is possible to apply a system of indicators of the environmental impact, based on the DPSIR methodology that will allow for both risk assessment procedures and methods of management influence on such indicators, as well as continuous monitoring and necessary adjustments in the project life cycle.

The application of control indicators of DPSIR model EEA in the development strategy of retail trade obtaining the impact on the environment and economic effect of the applied technologies is possible by optimization of some technological and organizational processes at the petrol/gas stations.

The use of LED technology in petrol/gas stations reduces energy consumption by $20 \%$. Reduce energy consumption by applying energy saving technologies enables the realization of measures to improve energy efficiency and other essential indicators for sustainable energy. 


\section{REFERENCES}

[1] Bajin D., Jovanović L., (2010) Energy efficiency in function of environment protection. Ecologica 59, 287-292.

[2] Black J. T., Kohser R.A., (2011) DeGarmo's materials and processes in manufacturing, John Wiley and Sons

[3] DeGarmo E.P., Black J.T., Kohser R.A., Klamecki B.E., (2003) Materials and Processes in Manufacturing, John Wiley and Sons

[4] EEA, DPSIR indicators, 2010.

[5] Jovanović L., Bajin D., (2011) Primena obnovljivih izvora energije u saobraćaju, Tematski zbornik radova, Međunarodna naučna konferencija "Energetska efikasnost železnice u funkciji održivog razvoja", Beograd, 21-32.

[6] Jovanovic L., Bajin D., (2012) Nove resursoštedljive tehnologije i savremeni ekološki problemi, Ecologica $67,331-336$.
[7] Jovanović L., Ermakov V., Čajka Z., (2014) Renewable energy resources in Serbia and Russia, Zaštita materijala 55, No 2, 133-141.

[8] Jovanović L.: Renewable energy resources in Serbia. In: Ermakov V.V. (ed.), (2013) Biogeochemistry and Biochemistry of trace elements under conditions of technogeneses of the biosphere, Proceedings of the VIII International Biogeochemical School, devoted to the 150th anniversary of the birth of V.I. Vernadsky, Grodno State University, Moscow: GEOKHI RAS, 2013, pp. 38-42.

[9] Hinckley James, Hinckley Jim, Robinson J.G., (2005) The Big Book of Car Culture: The Armchair Guide to Automotive Americana, Motorbooks International

[10] Oettel H., Schumann H. (Eds.), (2011) Metallografie: mit einer Einführung in die Keramografie. John Wiley and Sons, p. 284.

[11] Sanders Jr, R.E., (2001) Technology innovation in aluminum products, JOM 53,No 2, 21-25.

\section{IZVOD}

\section{OPTIMIZACIJA RAZVOJNIH PROCESA NA MREŽAMA BENZINSKIH PUMPI U CILJU POVEĆANJA ENERGETSKE EFIKASNOSTI}

Razvoj mreže benzinskih pumpi zahteva kompleksan pristup proceni uticaja na životnu sredinu. Upotreba odgovarajućih indikatora prema DPSIR metodologiji omogućava optimizaciju procesa na benzinskim pumpama i povećanje energetske efikasnosti.

Korišćenje obnovljivih izvora energije i novih izolacionih materijala ima veliki značaj za smanjenje potrošnje energije za grejanje zgrada benzinskih stanica. Kao zamenu za stiropor i stirodur (za dodatnu izolaciju zidova i podova) i za izgradnju novih objekata mnogo je efikasnije koristiti blokove od inovativnih izolacionih materijala.

Široka primena obnovljivih izvora energije $i$ termoizolacionih materijala u zgradama benzinskih stanica, smanjenje potrošnje električne energije korišćenjem LED tehnologija, kao i uštede goriva $u$ transportu usled smanjene težine cisterni načinjenih od Al legura $i$ kompozitnih materijala predstavljaju osnovne metode povećanja energetske efikasnosti. Upotreba Al legura u konstrukciji cisterni i rezervoara, takođe, povećava otpornost na koroziju.

Ključne reči: benzinska pumpa, optimizacija, DPSIR metodologija, indikatori, energetska efikasnost, obnovljivi izvori energije, LED tehnologija, otpornost na koroziju, Al legure.

Originalni naučni rad

Primljeno za publikovanje: 15. 09. 2014.

Prihvaćeno za publikovanje: 20. 11. 2014. 